Eurasian Studies in Business and Economics 16/2 Series Editors: Mehmet Huseyin Bilgin · Hakan Danis

Mehmet Huseyin Bilgin Hakan Danis

Ender Demir

Sofia Vale Editors

Eurasian
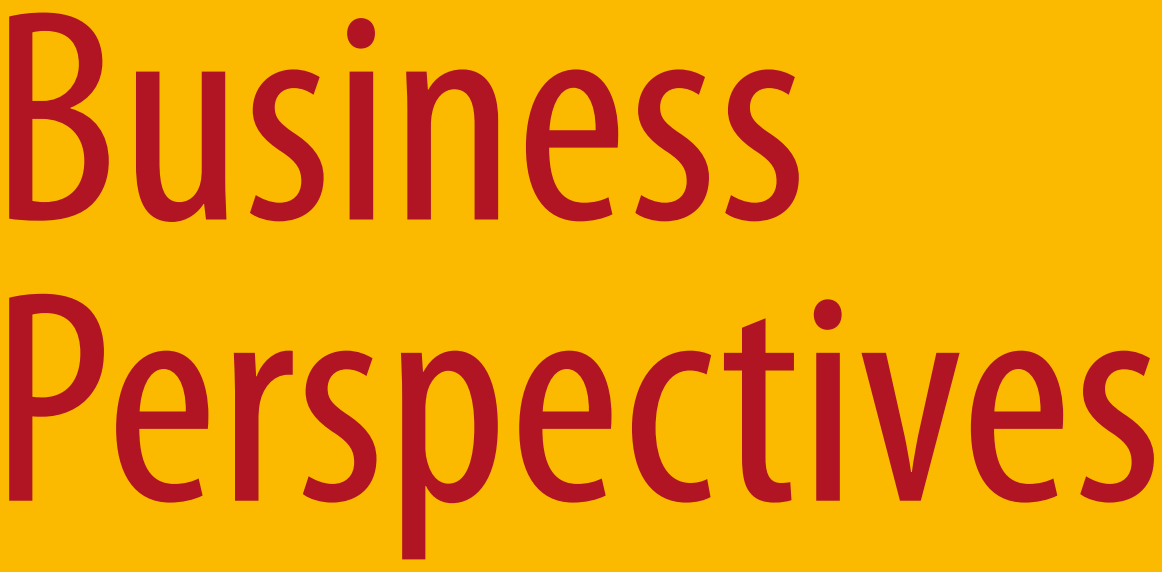

Proceedings of the 29th Eurasia Business and Economics Society Conference 


\section{Eurasian Studies in Business and Economics 16/2}

\section{Series Editors}

Mehmet Huseyin Bilgin, Istanbul, Turkey

Hakan Danis, San Francisco, CA, USA

Representing

Eurasia Business and Economics Society 
More information about this series at http://www.springer.com/series/13544 
Mehmet Huseyin Bilgin - Hakan Danis • Ender Demir - Sofia Vale

Editors

\section{Eurasian Business Perspectives}

Proceedings of the 29th Eurasia Business and Economics Society Conference

包 Springer 


\section{Editors}

Mehmet Huseyin Bilgin

Faculty of Political Sciences

Istanbul Medeniyet University

Istanbul, Turkey

\section{Ender Demir}

Faculty of Tourism

Istanbul Medeniyet University

Istanbul, Turkey

\author{
Hakan Danis \\ MUFG Union Bank \\ San Francisco, California, USA
}

\author{
Sofia Vale \\ Department of Economics \\ ISCTE-IUL Iscte - Instituto Universitário de \\ Lisboa \\ Lisbon, Portugal
}

The authors of individual papers are responsible for technical, content, and linguistic correctness.

ISSN 2364-5067

ISSN 2364-5075 (electronic)

Eurasian Studies in Business and Economics

ISBN 978-3-030-65084-1 ISBN 978-3-030-65085-8 (eBook)

https://doi.org/10.1007/978-3-030-65085-8

(C) The Editor(s) (if applicable) and The Author(s), under exclusive license to Springer Nature Switzerland AG 2021

This work is subject to copyright. All rights are solely and exclusively licensed by the Publisher, whether the whole or part of the material is concerned, specifically the rights of translation, reprinting, reuse of illustrations, recitation, broadcasting, reproduction on microfilms or in any other physical way, and transmission or information storage and retrieval, electronic adaptation, computer software, or by similar or dissimilar methodology now known or hereafter developed.

The use of general descriptive names, registered names, trademarks, service marks, etc. in this publication does not imply, even in the absence of a specific statement, that such names are exempt from the relevant protective laws and regulations and therefore free for general use.

The publisher, the authors, and the editors are safe to assume that the advice and information in this book are believed to be true and accurate at the date of publication. Neither the publisher nor the authors or the editors give a warranty, expressed or implied, with respect to the material contained herein or for any errors or omissions that may have been made. The publisher remains neutral with regard to jurisdictional claims in published maps and institutional affiliations.

This Springer imprint is published by the registered company Springer Nature Switzerland AG.

The registered company address is: Gewerbestrasse 11, 6330 Cham, Switzerland 


\section{Preface}

This is Volume 2-Eurasian Business Perspectives-of the 16th issue of the Springer's series Eurasian Studies in Business and Economics, which is the official book series of the Eurasia Business and Economics Society (EBES, www. ebesweb.org). This issue includes selected papers presented at the 29th EBES Conference-Lisbon that was held on October, 10-12, 2019, in Lisbon, Portugal. The conference is hosted by the ISCTE-IUL Instituto Universitário de Lisboa.

Amine Tarazi from the University of Limoges, France, Robert William Vivian from the University of the Witwatersrand, South Africa, and Christo Auret from the University of the Witwatersrand, South Africa, joined the 29th EBES Conference as keynote speakers. During the conference, participants had many productive discussions and exchanges that contributed to the success of the conference where 312 papers by 551 colleagues from 52 countries were presented. In addition to publication opportunities in EBES journals (Eurasian Business Review and Eurasian Economic Review, which are also published by Springer), conference participants were given the opportunity to submit their full papers for this issue. Theoretical and empirical papers in the series cover diverse areas of business, economics, and finance from many different countries, providing a valuable opportunity to researchers, professionals, and students to catch up with the most recent studies in a diverse set of fields across many countries and regions.

The aim of the EBES conferences is to bring together scientists from business, finance, and economics fields, attract original research papers, and provide them with publication opportunities. Each issue of the Eurasian Studies in Business and Economics covers a wide variety of topics from business and economics and provides empirical results from many different countries and regions that are less investigated in the existing literature. All accepted papers for the issue went through a peer review process and benefited from the comments made during the conference as well. The current issue covers fields such as human resources, management, and marketing.

Although the papers in this issue may provide empirical results for a specific county or regions, we believe that the readers would have an opportunity to catch up 
with the most recent studies in a diverse set of fields across many countries and regions and empirical support for the existing literature. In addition, the findings from these papers could be valid for similar economies or regions.

On behalf of the series editors, volume editors, and EBES officers, I would like to thank all the presenters, participants, board members, and keynote speakers, and we are looking forward to seeing you at the upcoming EBES conferences.

Best regards

Istanbul, Turkey

Ender Demir 


\section{Eurasia Business and Economics Society (EBES)}

$E B E S$ is a scholarly association for scholars involved in the practice and study of economics, finance, and business worldwide. EBES was founded in 2008 with the purpose of not only promoting academic research in the field of business and economics but also encouraging the intellectual development of scholars. In spite of the term "Eurasia," the scope should be understood in its broadest terms as having a global emphasis.

EBES aims to bring worldwide researchers and professionals together through organizing conferences and publishing academic journals and increase economics, finance, and business knowledge through academic discussions. Any scholar or professional interested in economics, finance, and business is welcome to attend EBES conferences. Since our first conference in 2009, around 12459 colleagues from 99 countries have joined our conferences and 7091 academic papers have been presented. EBES has reached 2375 members from 87 countries.

Since 2011, EBES has been publishing two journals. One of those journals, Eurasian Business Review-EABR, is in the fields of industrial organization, innovation, and management science, and the other one, Eurasian Economic Review-EAER, is in the fields of applied macroeconomics and finance. Both journals are published quarterly by Springer and indexed in Scopus. In addition, EAER is indexed in the Emerging Sources Citation Index (Clarivate Analytics) and EABR is indexed in the Social Science Citation Index (SSCI) with an impact factor of $\mathbf{2 . 2 2 2}$ as of 2019 .

Furthermore, since 2014 Springer has started to publish a new conference proceedings series (Eurasian Studies in Business and Economics) which includes selected papers from the EBES conferences. The 10th, 11th, 12th, 13th, 14th, 15th, 16th, 17th, 18th, 19th, 20th (Vol. 2), and 24th EBES Conference Proceedings have already been accepted for inclusion in the Conference Proceedings Citation Index-Social Science \& Humanities (CPCI-SSH). Subsequent conference proceedings are in progress. 
We look forward to seeing you at our forthcoming conferences. We very much welcome your comments and suggestions in order to improve our future events. Our success is only possible with your valuable feedback and support!

With my very best wishes,

Klaus F. Zimmermann

President

\section{EBES Executive Board}

Klaus F. Zimmermann, UNU-MERIT \& Maastricht University, The Netherlands Jonathan Batten, RMIT University, Australia

Iftekhar Hasan, Fordham University, USA

Euston Quah, Nanyang Technological University, Singapore

John Rust, Georgetown University, USA

Dorothea Schafer, German Institute for Economic Research DIW Berlin, Germany Marco Vivarelli, Università Cattolica del Sacro Cuore, Italy

\section{EBES Advisory Board}

Ahmet Faruk Aysan, Istanbul Sehir University, Turkey

Michael R. Baye, Kelley School of Business, Indiana University, USA

Mohamed Hegazy, The American University in Cairo, Egypt

Cheng Hsiao, Department of Economics, University of Southern California, USA

Noor Azina Ismail, University of Malaya, Malaysia

Irina Ivashkovskaya, State University - Higher School of Economics, Russia

Christos Kollias, University of Thessaly, Greece

Wolfgang Kürsten, Friedrich Schiller University Jena, Germany

William D. Lastrapes, Terry College of Business, University of Georgia, USA

Sungho Lee, University of Seoul, South Korea

Justin Y. Lin, Peking University, China

Brian Lucey, The University of Dublin, Ireland

Rita Martenson, School of Business, Economics and Law, Goteborg University, Sweden

Steven Ongena, University of Zurich, Switzerland

Peter Rangazas, Indiana University-Purdue University Indianapolis, USA

Peter Szilagyi, Central European University, Hungary

Amine Tarazi, University of Limoges, France

Russ Vince, University of Bath, United Kingdom

Adrian Wilkinson, Griffith University, Australia

Naoyuki Yoshino, Keio University, Japan 


\section{Organizing Committee}

Klaus F. Zimmermann, $\mathrm{PhD}$, UNU-MERIT \& Maastricht University, The Netherlands

Mehmet Huseyin Bilgin, $\mathrm{PhD}$, Istanbul Medeniyet University, Turkey

Hakan Danis, PhD, Union Bank, USA

Alina Klonowska, $\mathrm{PhD}$, Cracow University of Economics, Poland

Orhun Guldiken, $\mathrm{PhD}$, University of Arkansas, USA

Ender Demir, $\mathrm{PhD}$, Istanbul Medeniyet University, Turkey

Sofia Vale, PhD, ISCTE Business School, Portugal

Jonathan Tan, PhD, Nanyang Technological University, Singapore

Ugur Can, EBES, Turkey

\section{Reviewers}

Sagi Akron, PhD, University of Haifa, Israel

Ahmet Faruk Aysan, PhD, Istanbul Sehir University, Turkey

Mehmet Huseyin Bilgin, PhD, Istanbul Medeniyet University, Turkey

Andrzej Cieślik, $\mathrm{PhD}$, University of Warsaw, Poland

Hakan Danis, PhD, Union Bank, USA

Ender Demir, $\mathrm{PhD}$, Istanbul Medeniyet University, Turkey

Oguz Ersan, PhD, Kadir Has University, Turkey

Conrado Diego García-Gómez, PhD, Universidad de Valladolid, Spain

Orhun Guldiken, $\mathrm{PhD}$, University of Arkansas, USA

Peter Harris, PhD, New York Institute of Technology, USA

Mohamed Hegazy, The American University in Cairo, Egypt

Gokhan Karabulut, $\mathrm{PhD}$, Istanbul University, Turkey

Alexander M. Karminsky, PhD, National Research University, Russia

Christos Kollias, $\mathrm{PhD}$, University of Thessaly, Greece

Davor Labaš, PhD, University of Zagreb, Croatia

Chi Keung Marco Lau, PhD, University of Huddersfield, United Kingdom

Veljko M. Mijušković, PhD, University of Belgrade, Serbia

Gregory Lee, PhD, University of the Witwatersrand, South Africa

Nidžara Osmanagić-Bedenik, $\mathrm{PhD}$, University of Zagreb, Croatia

Euston Quah, PhD, Nanyang Technological University, Singapore

Peter Rangazas, $\mathrm{PhD}$, Indiana University-Purdue University Indianapolis, USA

Doojin Ryu, PhD, Chung-Ang University, South Korea

Uchenna Tony-Okeke, PhD, Coventry University, United Kingdom

Sofia Vale, PhD, ISCTE Business School, Portugal

Manuela Tvaronavičienè, $\mathrm{PhD}$, Vilnius Gediminas Technical University, Lithuania

Marco Vivarelli, $\mathrm{PhD}$, Università Cattolica del Sacro Cuore, Italy 


\section{Contents}

\section{Part I Human Resources Management}

The Impact of Supervisor Support on Employee-Related Outcomes

Through Work Engagement . . . . . . . . . . . . . . . . 3

Maria Leonor Pires

Level of Similarity of Team Management with the Use of System of Organizational Terms . . . . . . . . . . . . . . . . . . .

Olaf Flak

A Novel, Competency-Based Approach of the HRM-Related Definition of Talent: A Suggestion Based on Theoretical and Empirical Findings . . .

Eszter Daruka and Katalin Pádár

\section{Part II Management}

Crisis Management: The Perspective of Organizational Learning . . . . 75 Jarema Batorski

Standardization of Global Logistics Business Operations . . . . . . . . .

Slobodan Aćimović, Veljko M. Mijušković, and Jovana Obradović

Can Performance Appraisal Satisfaction Improve Performance?

A Study at Indonesian Universities . . . . . . . . . . . . . . .

Ietje Nazaruddin, Hafiez Sofyani, Fitri Wahyuni, and Erni Suryandari

Team Viability: Mission Impossible or Feasible? Threats for Team

Viability in Contemporary Polish Organizations

Iwona Janiak-Rejno, Agnieszka Żarczyńska-Dobiesz, and Barbara Chomątowska

On the Issue of Implementation of Agile and Strategy as a Practice Mixed-Method in Strategic Planning

Elena Serova and Oleg Kalmykov 
Business Model Analysis of Veterinary Clinic: The Case Study . . . . . . . 141 Karolina Beyer

Is Higher Level of Trust in Organizations Always Positively Correlated with Higher Economic Results? Evidence from Estonian Farms . . . . . . . 153 Mare Kurvits and Angela Jarvis

Ideologies at Work in Organizations: An Emerging Critical Perspective and Reflexive Research Agenda . . . . . . . . . . . . . . . . . . . 165

Severin Hornung, Thomas Höge, and Christine Unterrainer

Contemporary Research and Analysis of Food Industry:

Case of Russian Restaurant Business Network Branch . . . . . . . . . . . . . 183

Elizaveta Fainshtein, Elena Serova, and Pavel Vorobyev

Quality Audit Indicators for Inbound Tourism: A Qualitative

Study on Malaysian Travel Agencies . . . . . . . . . . . . . . . . . . . . . 201

Mazni Saad, Afiza Mohamad Ali, Zahid Ismail, and Nor Hafizah Mohd Arop

\section{Part III Marketing}

Supportive Elements of a Long-Term B2B Communication:

The Case of a Norwegian SME

Karoline Hjelmeland and Elena Panteleeva

Differences in Consumer Behavior from the Viewpoint of Education and Gender .

Tatiana Pethö, Robert Štefko, and Ivana Ondrijová

Omnichannel Strategies Under the Marketing 4.0 Paradigm:

Conceptual Structure and Current Applications

V. Özlem Akgün and Emel Celep

The Relationship Between Logo Changes and Brand Equity

in Creating Brand Awareness .

Meltem Diktaş and V. Özlem Akgün

Framework of Marketing Performance Measurement and

Management

Asta Kamandulienè and Lina Pilelienè

Consumers' Influence in Online Social Networks Regarding

Recycling Habits .

Camelia Delcea, Liviu-Adrian Cotfas, Rafal Mierzwiak, and Mihai Orzan

From the 4 Ps to 5 Ps: Prompt, a New Element for the Marketing Mix:

A Specific Analysis of the Coffee Market: The Portuguese Market . . . . . 307

Sílvia Faria and Pedro Ferreira 
An Investigation on Voluntary Simplicity Movement in the Context of Sustainable Consumption Behavior Against the Overconsumption

Tendency .

Emel Celep and Meltem Diktaş

Students' Perception of Quality in Higher Education:

Evidence from the Polytechnic in Croatia

Mirjana Jeleč Raguž, Verica Budimir, and Svjetlana Letinić

Rationalization as New Trend in Food Behavior of Polish Consumers . . . 347

Gabriela Hanus 


\section{Contributors}

Slobodan Aćimović Faculty of Economics, University of Belgrade, Belgrade, Serbia

V. Özlem Akgün Faculty of Economics and Administrative Sciences, Department of International Trade, Selcuk University, Konya, Turkey

Afiza Mohamad Ali Department of English, Kulliyyah of Languages and Management, International Islamic University Malaysia, Johor, Malaysia

Nor Hafizah Mohd Arop Malaysia Productivity Corporation, Lorong Produktiviti, Selangor, Malaysia

Jarema Batorski Institute of Entrepreneurship, Jagiellonian University, Cracow, Poland

Karolina Beyer Institute of Management, University of Szczecin, Szczecin, Poland

Verica Budimir Social Department, Polytechnic in Pozega, Pozega, Croatia

Emel Celep Faculty of Economics and Administrative Sciences, Department of Business Administration, Selcuk University, Konya, Turkey

Barbara Chomątowska Department Production and Labour Management, Wroclaw University of Economics and Business, Wroclaw, Poland

Liviu-Adrian Cotfas Department of Economic Informatics and Cybernetics, Bucharest University of Economic Studies, Bucharest, Romania

Eszter Daruka Department of Management and Business Law, Institute of Business Economics, Eötvös Loránd University, Budapest, Hungary

Camelia Delcea Department of Economic Informatics and Cybernetics, Bucharest University of Economic Studies, Bucharest, Romania

Meltem Diktaş Department of Administration and Organization, Selçuk University, Konya, Turkey 
Kadınhanı Vocational High School, Department of Management and Organization, Local Administrations Program, Selcuk University, Konya, Turkey

Elizaveta Fainshtein Department of Management, National Research University Higher School of Economics, St. Petersburg, Russian Federation

Sílvia Faria Faculdade de Economia e Gestão, Universidade Portucalense, Porto, Portugal

Pedro Ferreira Faculdade de Economia e Gestão, Universidade Portucalense, Porto, Portugal

Olaf Flak Krzysztof Kieslowski Film School, University of Silesia in Katowice, Katowice, Poland

Gabriela Hanus Department of Business Logistics, University of Economics in Katowice, Katowice, Poland

Karoline Hjelmeland Department of International Business, Norwegian University of Science and Technology, Aalesund, Norway

Thomas Höge Institute of Psychology, University of Innsbruck, Innsbruck, Austria Severin Hornung Institute of Psychology, University of Innsbruck, Innsbruck, Austria

Zahid Ismail Malaysia Productivity Corporation, Lorong Produktiviti, Selangor, Malaysia

Iwona Janiak-Rejno Department Production and Labour Management, Wroclaw University of Economics and Business, Wroclaw, Poland

Angela Jarvis Estonian Entrepreneurship University of Applied Sciences, Tallinn, Estonia

Oleg Kalmykov Management Department, National Research University Higher School of Economics, St. Petersburg, Russian Federation

Asta Kamandulienè Faculty of Economics and Management, Vytautas Magnus University, Kaunas, Lithuania

Mare Kurvits Estonian Entrepreneurship University of Applied Sciences, Tallinn, Estonia

Svjetlana Letinić Social Department, Polytechnic in Pozega, Pozega, Croatia

Tatiana Lorincová Department of Managerial Psychology, Prešov University in Prešov, Prešov, Slovakia

Rafal Mierzwiak Department of Marketing and Economic Control, Poznan University of Technology, Poznan, Poland

Veljko M. Mijušković Faculty of Economics, University of Belgrade, Belgrade, Serbia 
Ietje Nazaruddin Department of Accounting, Universitas Muhammadiyah Yogyakarta, Yogyakarta, Indonesia

Jovana Obradović Milsped Company, Belgrade, Serbia

Ivana Ondrijová Department of Managerial Psychology, Prešov University in Prešov, Prešov, Slovakia

Mihai Orzan Department of Marketing, Bucharest University of Economic Studies, Bucharest, Romania

Katalin Pádár Department of Management and Business Law, Institute of Business Economics, Eötvös Loránd University, Budapest, Hungary

Elena Panteleeva Department of International Business, Norwegian University of Science and Technology, Aalesund, Norway

Lina Pilelienė Faculty of Economics and Management, Vytautas Magnus University, Kaunas, Lithuania

Maria Leonor Pires Secção Autónoma de Ciências Empresariais e Comunicação, IPS/ESTSetúbal, Setúbal, Portugal

Mirjana Jeleč Raguž Social Department, Polytechnic in Pozega, Pozega, Croatia

Mazni Saad Department of Tourism, Kulliyyah of Languages and Management, International Islamic University Malaysia, Johor, Malaysia

Elena Serova Department of Management, National Research University Higher School of Economics, St. Petersburg, Russian Federation

Hafiez Sofyani Department of Accounting, Universitas Muhammadiyah Yogyakarta, Yogyakarta, Indonesia

Robert Štefko Department of Marketing and International Trade, Prešov University in Prešov, Prešov, Slovakia

Erni Suryandari Department of Accounting, Universitas Muhammadiyah Yogyakarta, Yogyakarta, Indonesia

Christine Unterrainer Institute of Psychology, University of Innsbruck, Innsbruck, Austria

Pavel Vorobyev Department of Management, National Research University Higher School of Economics, St. Petersburg, Russian Federation

Fitri Wahyuni Department of Accounting, Universitas Muhammadiyah Yogyakarta, Yogyakarta, Indonesia

Agnieszka Żarczyńska-Dobiesz Department Production and Labour Management, Wroclaw University of Economics and Business, Wroclaw, Poland 


\title{
Quality Audit Indicators for Inbound Tourism: A Qualitative Study on Malaysian Travel Agencies
}

\author{
Mazni Saad, Afiza Mohamad Ali, Zahid Ismail, and \\ Nor Hafizah Mohd Arop
}

\begin{abstract}
Quality assurance is fundamental to all business activities in the tourism sector as it is advantageous to market recognition and competitiveness. Awareness of the importance of quality assurance certifications is already in place in Malaysia; however, it is still under-researched. Thus, this study aims to investigate how local travel agency operators perceive suitable levels of quality audit indicators for inbound travel agencies. A semi-structured interview was conducted to explore the views and experiences of key industry players from five travel agencies involved in both inbound and outbound tourism businesses in the country. A content analysis of data acknowledged the industry's increased awareness of quality service delivery and the importance of rationalizing key quality audit indicators in assuring the lifelong survival of inbound Malaysian travel agencies. Also found was the need for systematic monitoring of the inbound travel agency's certification plan that continually reflects the demands of the clientele and uplifts national productivity as outlined in the initiatives undertaken by the Tourism Productivity Nexus, an industry-led establishment under the Malaysia Productivity Blueprint 2016-2020. The study finally outlines specific entrepreneurial strategies that will enhance productivity operations at the enterprise level.
\end{abstract}

Keywords Certifications · Inbound tourism · Quality assurance · Quality indicators · Travel agency

\footnotetext{
M. Saad $(\bowtie)$

Department of Tourism, Kulliyyah of Languages and Management, International Islamic University Malaysia, Johor, Malaysia

e-mail: maznisaad@iium.edu.my
}

A. Mohamad Ali

Department of English, Kulliyyah of Languages and Management, International Islamic University Malaysia, Johor, Malaysia

e-mail: drfiza@iium.edu.my

Z. Ismail · N. H. Mohd Arop

Malaysia Productivity Corporation, Lorong Produktiviti, Selangor, Malaysia

e-mail: Zahid@mpc.gov.my; Hafizah@mpc.gov.my 


\section{Introduction}

The tourism industry has received a very positive growth in recent years. In 2018, tourists' arrival was 25.83 million with MYR84.1 billion tourist receipts. The number of receipts from the tourists has considerably increased by $41 \%$ than it had just 10 years ago (Tourism Malaysia 2019). Through a travel agent, tourists are introduced to the right attractions of a country based on their interests, so they prefer a travel agent who has an in-depth knowledge of the country. In the emergence of the internet, the tourism sector can be sustainable through the involvement of inbound travel agencies for the human touch and real interactions the agencies have to offer. In 2018, local travel agencies have been identified as one of the main sources of information for inbound tourists to Malaysia. In January to March 2019, the Departing Visitors Survey recorded that travel agents played an important role, determined by $32.3 \%$ of the total source of information for the inbound tourism (Tourism Malaysia 2019).

Quality assurance for inbound tourism from the perspective of tourists can be measured from the services given. Singh et al. (2016) observed that the certification standards could have a significant impact in promoting the concept of sustainable tourism development. In Malaysia, the Tourism Productivity Nexus, an industry-led establishment under the Malaysia Productivity Blueprint 2016-2020, undertakes the effort in developing the standards for travel agencies as a support to the current policies regulating the business activities by the travel agencies in Malaysia under one of Tourism Productivity Nexus initiatives (Tourism Productivity Nexus 2019). Under the Nexus, stages and aspects in developing the industry standards and certification program for tourism products and services in Malaysia are adopted from a document by the World Tourism Organization (WTO) published in 2003 on recommendations to governments for supporting and/or establishing national certification systems for sustainable tourism (World Tourism Organization 2004). The document proposed the necessary steps toward building a certification program and guidelines on criteria, sub-criteria, and indicators.

On 8 May 2017, the prime minister of Malaysia launched the Malaysia Productivity Blueprint 2016-2020 which aims to achieve an annual labor productivity growth of $3.7 \%$ by 2020 (Azahar 2020). The Blueprint works at the national, sectoral, and enterprise level to address the challenges related to workforce talent, technology adaptability, incentive structures, business environment, and productivity mindset. At the sectoral level, the Blueprint has identified nine priority sub-sectors which cumulatively contribute to $30 \%$ of Malaysia's gross domestic product (GDP) and 40\% of total employment (Azahar 2020). They are retail and food and beverages $(F \& B)$, electrical and electronics $(\mathrm{E} \& \mathrm{E})$, chemicals and chemical products, agro-food, professional services, tourism, information and communications technology (ICT), machinery and equipment, and private healthcare. Sectorallevel initiatives under the nine sub-sectors are undertaken by the establishment of Productivity Nexus for the respective sub-sector, and they are led by industry players 
Table 1 Thirteen main areas under MyTQA

\begin{tabular}{ll|ll}
\hline 1. & Culture and heritage & 8. & Parks and gardens \\
\hline 2. & Nature and adventure & 9. & Agro parks \\
\hline 3. & Man-made & 10. & Theme parks \\
\hline 4. & Sports and recreation & 11. & Tourism restaurants \\
\hline 5. & Shopping & 12. & Places of worship \\
\hline 6. & Cruise and sails & 13. & Traditional market bazaar \\
\hline 7. & Islands and beaches & & \\
\hline
\end{tabular}

Source: Malaysia Tourism Quality Assurance (MyTQA) (2020)

supported by Malaysia Productivity Corporation, an agency under Malaysia's Ministry of International Trade and Industry.

Tourism Productivity Nexus is one of the nexuses established to assist businesses to enhance productivity, increase innovation, and capture development opportunities within the tourism industry in Malaysia. Tourism Productivity Nexus' priority initiatives as stipulated in the Blueprint are to:

1. Strengthen cooperative efforts between industry and academia to match industry needs

2. Establish a certification/accreditation program for tourism products

3. Review the pricing system

4. Review industry standards and regulations based on industry's input,

5. Align marketing strategy according to market segments

Initiative number two, that is, to establish a certification/accreditation program, commenced its developmental stages in April 2019. Engagements with major stakeholders in the tourism industry and certification in the tourism industry have unveiled key issues in the certification of tourism products and services. One of the challenges is the inadequacy of standards or certification which tourism product and service owners can subscribe to in Malaysia. This is especially true for small and medium tourism enterprises and micro-companies.

Regulating tourism through certification schemes is now a strategy or a means for many countries particularly in encouraging sustainable services (Medina 2005). Certification is a workable tool to rally tourism industry players around the common aim of standard implementation to enhance the sustainable development of the tourism industry (Font 2005). In Australia, certification and accreditation of tourism products and services are centralized within its Quality Tourism Framework (Australian Tourism Industry Council 2019).

In Malaysia, the Ministry of Tourism, Arts, and Culture Malaysia (MoTAC) has developed Malaysia Tourism Quality Assurance (MyTQA). MyTQA covers 13 categories as demonstrated in Table 1.

Despite such efforts, MoTAC's official website listed only 39 companies who have voluntarily subscribed to MyTQA since it was launched (Ministry of Tourism, Arts and Culture Malaysia 2020), and there seemed to be no specific quality assurance standards and certifications for travel agencies. Furthermore, the 
national-level standards currently include 14 standards specific to the tourism industry, but none has covered the travel agency.

Studies have shown the consensus reached by travel agencies on the potential increase of the predictive power and positive implications of certification and standardization toward the management, marketing, and finance of the travel business (Mak 2015; Singh et al. 2016). However, in Malaysia, there seemed to be inadequate standards and certification programs for inbound travel agencies. Travel agencies in Malaysia are currently regulated by the MoTAC, but there is no specific standard or certification program by which the agencies can refer or subscribe to in standardizing their operations and management. In addition, rules and policies exist to provide the legal foundation for travel agencies' operations, but there is still a lack of standardization on how their activities and services may be performed.

It is thus timely that the initiative to establish a tourism certification program be extended to services provided by travel agencies through standards development true to their operations. The industry-level standards for inbound travel agencies are expected to strengthen and standardize the operations of travel agencies, enhance their service quality, and expand their businesses to the next level. Despite this, the lack of indicators in order to serve the demands of specific certification in the travel agency in general is paramount. Thus, this study aims to investigate local travel agency operators' perception of suitable quality audit indicators for inbound travel agencies in Malaysia. This paper is organized as follows: Section 2 will review relevant literature based on the objective of the study, followed by the research method that was undertaken in Sect. 3. Then, Sect. 4 presents and discusses the findings of the study, while Sect. 5 concludes the paper with a summation of the main outcomes, recommendations, and implications of the study.

\section{Literature Review}

\subsection{Quality Audit Indicators in Tourism}

A considerable amount of literature has been published on quality audit indicators as means to highlight the importance of good service delivery standards and assurance (Budimir et al. 2016; Teng et al. 2012; Xin and Chan 2014). Quality assurance certification is the outcome from quality performance indicators, which are set as the measurement to improve service delivery through standard, evidence-based measures and highlight quality improvement over time. Good quality indicators are thus useful to assist in decision-making, risk awareness, business forecast, and performance measurement (Xin and Chan 2014). As stated by the World Tourism Organization (2004), indicators allow stakeholders access to information crucial for them to be accounted for in the business, based on a monitoring system or certification that can be developed for continuous improvement.

Teng et al. (2012) reported 11 indicators as the common standards for certification programs in Taiwan for a green hotel to operate. The criteria of the indicators are 
compliance to water, energy, waste, corporate environmental management, staff involvement, guest information, indoor environment quality, hazardous substances, social involvement and communication, purchasing, transport, and food and beverage. A study by Xin and Chan (2014) on tour operators' perspectives to develop responsible tourism indicators at Kinabalu National Park in the state of Sabah in Malaysia found four themes of indicators and 17 core indicators, which included the management of the destination as well as economical, ecological, social, and cultural value and aspects. The study aimed to take into consideration the importance of obtaining stakeholders' input to develop quality indicators for responsible tourism for sustainable development.

In Norway, the country experiences a visible certification schemes on green travel options. The tourism industry is principled on sustainability and green environment (Norway 2020). Certification is seen crucial; for example, over 100 strict indicators were set for Ecotourism Norway on environmental performance, host role, local community integration, and purchasing. In the case of Star Ratings Australia, the indicators are determined by more than 200 indicators which have been ranked by travelers on quality accommodation which reflects cleanliness, quality, and condition of facilities (https://www.starratings.com.au/). In the United Kingdom, Mellina and Reino (2019) found that online review rating or electronic word-of-mouth (eWOM) plays a significant role in the hotel's classifications.

\subsection{Suitable Quality Audit Indicators for Local Travel Agency Operators}

It is mainly important to understand how local travel agency operators perceive suitable levels of quality audit indicators as they lead the industry. For example, performance and management play important roles in the tourism business quality. In China, the policy and strategies from the government-led travel agency formed the organizational behavior in the country (Huang and Chen 2016).

Business information is another important indicator. Perramon et al. (2015) stated that customer-driven companies must adapt to the demands of the market. Thus, the travel agency companies require a complete and efficient information system to monitor workers' performance, cost-benefit analyses, benchmarking, or identification of new business opportunities. Virtual presence of inbound travel agencies is important, and online platforms allow for customer reviews by understanding their demands.

Inbound travel agencies are mainly small and medium enterprises who also need competent manpower. The recruitment of competent staff is essential physically and virtually. Besides ground operations, travel agencies must also be alert to the growing needs of customers via online technology. Kalbaska and Cantoni (2018) in their study on the e-learning strategies among travel agents in the United Kingdom, India, and New Zealand showed how travel agents are perpetually strategizing 
themselves online. The study used phone interviews for education and certification in the travel trade. Hiring competent staff will expedite the operation of travel agencies, but it is also crucial for the staff to be able to act as if they are the business owner.

Also pertinent to the inbound travel agency is their local guide's quality and expertise. The travel agency needs to make sure their guides are abreast with issues pertaining to the travel business, changing rules and regulations, and trends for absolute customer satisfaction. In recent developments, which are in line with IR 4.0, the interactive electronic guides are a great help for the tourism business (Tarantino et al. 2019). Most challenges faced by travel agencies are the constraints in safety and security issues in the visited destinations. The acts of political and social turmoil, terrorism, military conflicts, or epidemics issues may be predicted in unstable countries. However, tourists may also face risks while travelling. In the case of Malaysia, AlBattat and Mat Som (2014) found that Malaysian tourism and hospitality industries are not fully ready to deal with the disasters. The study also emphasized the power of online media to help the marketing activities to work on the publicity for safe inbound tourism. Unsafe reports by the media can influence tourists negatively; hence, the state government and industry players need to take proactive approaches to the crisis and disaster management (Mat Som et al. 2015).

Basic facilities like an office, technology, and transportation are the bases for the inbound travel agency. Unlike manufacturing and other industries, tourism and hospitality industries are highly dependent on information service management. A study has proven the mediating effects of the facility on the quality practices and financial performance in the travel agencies (Perramon et al. 2015). Technologically enhanced analytical capabilities (artificial intelligence) and rich media (virtual and augmented reality) are creating smart environments that are transforming industry structures, processes, and practices. Accurate systems and quality training of staff should henceforth be in place at the travel agencies.

In a highly competitive business, first impression matters. Travel agents are expected to be experienced and knowledgeable as to best match the personality of clients to the most suitable options and destination. As the travel agency is selling travel services on behalf of the operators for hotels, airlines, tours, cruise lines, and other travel providers, the agency has no control over many situations. However, they can make sure that the physical and virtual information like signages, reservations, and itineraries are set to avoid potential problems so customers would continue on their choices with the least amount of difficulty or stress. This personality may give the first and last impression on the travel agency.

The last but not least indicator is the sustainable practices. Sustainable practice is a social practice and about the occupant behavior engaged in the office building (King 2019). This contemporary practice may be associated with the design of the office buildings in relation to the technological, physical, and economic aspects as well as to the social and psychological considerations (Hoffman and Henn 2008). The rise of personal computers within nine to five working hours, for instance, led to hot-desking and, therefore, requires appropriate office space, light, air quality, temperature and controlled noise. The ambience in the travel business creates 
value co-creation and enriches the customer experience. These elements need to be consistent based on suitable sustainable best practices for the long-term survival of the tourism industry. The travel agencies that work on sustainability apparently score better on customer satisfaction, staff motivation, and business efficiency, with positive effects for their competitive advantage (Chan 2010).

These studies have highlighted some important criteria expected from travel agencies, but the lack of research on the development of standard indicators that can be used for inbound travel agencies as a whole is discernible. Hence, the study aims to gauge suitable quality audit indicators for inbound tourism agents from the Malaysian travel agencies' perspective as part of ensuring the future of continuous quality service in the sector for market recognition and competitiveness.

\section{Research Methodology}

The research design undertook a qualitative approach via focus group interviews. Focus groups are regarded as a collaborative research method, "as the outcome is dependent on the interactions of group members as well as interactions with the facilitator" (Cater and Low 2012, p. 354). In addition, according to Picken (2017), interviewing methods are very useful to get a deeper understanding of a topic dealing with probable and relevant differences in perception, attitude, impacts, behaviors, and practices. These variances are seen between groups of people (like stakeholders) or between individuals. Semi-structured interview questions were employed in the study to elicit insightful opinions of respondents and develop a descriptive content of inbound tourism quality criteria and indicators. The open-ended questions or items were formulated based on the available literature on quality indicators research in tourism. This also enabled the interview to be more inductive, reflexive, and flexible in nature to allow for possible content to be covered or emerge. Basically, the interview addressed questions on the nature, scopes, and guiding principles in developing the criteria and sub-criteria/indicators for Malaysian inbound travel agencies as well as the future of quality service monitoring in the sector.

The main target groups for the standards and certification program developed by Tourism Productivity Nexus were small-medium tourism enterprises and microcompanies. Small-medium tourism enterprises account for about $85 \%$ of tourism businesses in Malaysia (Set 2013). Currently, there are 4790 registered travel agencies in Malaysia, and around $80 \%$ of them are small and medium companies (Ministry of Tourism, Arts and Culture Malaysia 2020). The sample interviewees included a chairman, chief executive officer, director, and general manager of four distinct Malaysian travel agencies as well as one secretary-general of the Malaysia Tourism Council. They have been the major players in the Malaysia tourism industry with more than 20 years of experience, which justified the sample selection. The focus group interview was digitally recorded and conducted in English. Data was transcribed and translated into English in cases where interviewees spoke in Malay. 
Table 2 Background information on participating organizations

\begin{tabular}{l|l|l}
\hline Interviewees & Background of organization & $\begin{array}{l}\text { Job position of } \\
\text { interviewees }\end{array}$ \\
\hline $\begin{array}{l}\text { 1. Inter- } \\
\text { viewee A }\end{array}$ & $\begin{array}{l}\text { Local company which was established in 1985 dealing with } \\
\text { tourism and hospitality business services } \\
\text { A member of the Malaysian Association of Tour and Travel } \\
\text { Agents (MATTA), the International Airlines \& Tourist } \\
\text { Association (IATA) and the Malaysian Bumiputra Travel } \\
\text { Agent Association (Bumiputra Malaysia) }\end{array}$ & Chairman \\
\hline $\begin{array}{l}\text { 2. Inter- } \\
\text { viewee B }\end{array}$ & $\begin{array}{l}\text { A licensed, private limited travel and tours company } \\
\text { established in 1986 for inbound and outbound tours, by the } \\
\text { MoTAC Malaysia. It is an accredited agent of IATA and } \\
\text { member of MATTA. It is also an authorized agent for } \\
\text { ticketing by several airlines including Malaysia Airlines }\end{array}$ & CEO \\
\hline $\begin{array}{l}\text { 3. Inter- } \\
\text { viewee C }\end{array}$ & $\begin{array}{l}\text { A licensed, private limited travel and tours company } \\
\text { established for more than 20 years for inbound and outbound } \\
\text { tours. It is an accredited agent of IATA and a member of the } \\
\text { Malaysian Inbound Tourism Association (MITA) }\end{array}$ & Director \\
\hline $\begin{array}{l}\text { 4. Inter- } \\
\text { viewee D }\end{array}$ & $\begin{array}{l}\text { Committee for Tourism Productivity Nexus (industry-led } \\
\text { establishment under Malaysia Productivity Corporation) }\end{array}$ & General manager \\
\hline $\begin{array}{l}\text { 5. Inter- } \\
\text { viewee E }\end{array}$ & $\begin{array}{l}\text { Malaysian Tourism Council (MTC), the main registered } \\
\text { tourism association in Malaysia }\end{array}$ & $\begin{array}{l}\text { Secretary- } \\
\text { general }\end{array}$ \\
\hline
\end{tabular}

The interview lasted for approximately 120 minutes. Table 2 shows the background information of the interviewees.

They were named as Interviewees A, B, C, D, and E, respectively, for anonymity purposes. Data were subjected to systematic content analysis in which the transcripts were read several times for overall understanding. This reflexive, nonlinear, and reiterative process is needed to identify and establish codes or categories while ensuring the meaning is retained (Erlingsson and Brysiewicz 2017). Coding of data was conducted by identifying themes or categories based on the predefined categories from the literature. Inter-rater validity and reliability of data analysis and interpretation were established by coming to a consensus for the findings to minimize or reduce bias.

\section{Results and Discussion}

\subsection{Suitable Quality Audit Indicators for Inbound Tourism Travel Agency Operators}

Findings showed that the first quality criteria agreed upon by the interviewees are related to the first impression of the agency. This was further divided into two sub-criteria, namely, the signages at agency entrance as well as at the office of the 
agency. In terms of the first sub-criteria, everyone agreed that the signages and directions to entrances and departments of agencies should be maintained in good condition and clearly shown to all. Interviewee A stated that "Certain things we need like signage to be well-maintained," and Interviewee A said, "My office must maintain the condition of signage." The interviewees positioned the office of the agency as sub-criteria 2 , with indicators like cleanliness and orderly and welcoming entrance to the attraction. Most importantly, all the directions to the agency and various departments of the office have to be clearly indicated or labelled. As stated by Interviewee A, "All departments signages must be clearly labelled at the office. But follows the tour, tour department. We actually got only a big travel agency. Inbound, outbound, ticketing departments." This indicator on the importance of proper information and communication of company sites is also mentioned by Xin and Chan (2014).

The second criterion is the business information of the travel agency as means for good product marketing services to customers. The first sub-criteria refer to telephone inquiries with promptness in answering calls and mention of the company's name with a wide knowledge of its products or tour packages as the indicators. According to Interviewee B, “. . . maybe telephone inquiries for this should be picked up at three rings." This is followed by the second sub-criterion which is the availability of leaflets, brochures, website, or social media presence of the travel agency. The quality indicators mentioned were having the images to represent the product and display of authorized contact details like telephone, website, email, social network services, QR code, and addresses; e.g., "Information on location, opening hours ... contact details are displayed. Everything should be included. Including location map" (Interviewee C).

Other indicators include usage of suitable graphics and/or photographs to describe the activities and facilities at the attraction (e.g., "There is a need to focus on images that represent the attraction's unique selling points" (Interviewee A)), availability of product and services (e.g., "it is good to put availability of transport service. But as availability of services. Because we don't only offer transport services but we offer other services too as travel agents" (Interviewee B)), and usage of suitable language for the target market pointed out by Interviewee D as part of marketing (e.g., "Foreign language is very important as staff needs to be fluent in English and or other appropriate languages. That's why we put simple appropriate language because it depends on what is marketing. For Arabs, he must talk Arab. So I may need someone speaking Arabic. If Korean, you have to have Korean"). The interviewees also approved the need for obtaining information on data and privacy protection and provision for customer review and frequently asked questions (FAQs) sections as important sub-indicators under business information which concur with the study by Perramon et al. (2015) on customer review importance.

The third sub-criteria under business information refer to booking and confirmation procedures. According to the findings, it is important for travel agencies to have proper booking and confirmation procedures to ensure reliable and trustworthy services to customers. Six indicators were mentioned, namely, the need to have an 
organized and systematic booking procedure (e.g., "We should put the booking procedure as an indicator. Must be organized. Booking and confirmation under one title" (Interviewee E)), a comprehensive itinerary (e.g., "Comprehensive itinerary already includes time to gather, what time departure, where to, what to do, what will be served etc. Quite a comprehensive itinerary needed" (Interviewee C), suitable activities according to age, medical fitness and others, clear information on risks of activities for customers, and suitable attire or apparatus for activities (e.g., "Agree that customers need to be informed of the tour itinerary, level of difficulty, possible hazards, safety precautions and regulations or rules that apply to their conduct on the tour" (Interviewee A)).

In addition to that, three more indicators are mentioned, that is, the need to attain confirmation of booking from customers and their data via email/social media such as their contact details apart from stating the terms and conditions of the package booked. For example, Interviewee B mentioned how social media is important as a means to communicate with customers on their visa application services; e.g., "Actually, social media like Facebook is something we fully utilize to communicate with customers. We recently used social media to inform us that we are doing Visa services."

The third criteria for inbound travel operators have to do with the facilities at the travel agency, namely, office, technology, and transportation, as its indicators. For the office, interviewees agreed that the agency office should follow the guidelines set by MoTAC. According to Interviewee C, "To register as a travel agent, you must have an office. This is all set in MoTAC's rules or terms and conditions for all registered travel agencies or operators. Like how many square meters. The office. You need to have signboards too." In addition, cleanliness of the premise is important as well, as it reflects the quality of the business and first impressions by customers. As mentioned by Interviewee A, "Because we deal with inbound customers, we go on local requirements for cleanliness. Must take care of cleanliness. You can't charge too high a price but not clean. So services include clean offices. This shows quality." This mention of facilities and their conditions as indicators echoes the important findings by Perramon et al. (2015). The second sub-criteria refer to technology and how travel agents should leverage digital marketing technology to promote their business and services. This understanding seems to relate to the need to have product digital applications for customers to easily access; as stated by Interviewee B, "I meet this Maybank guy 'do you have our apps? Give me your phone' he said. He downloaded the app and gave it to me. So, now, I don't need to type www.maybank.com.my. So, I just go to Maybank, I get my Maybank."

As for sub-criteria 3, e.g., transportation, findings from the interviews revealed that there is a need for travel agents to ensure inspections are met out on safety equipment accessibility and functionality at the premises. This indicator needs to be coupled with evidence of permit, insurance, and inspections by the local authorities like Puspakom, the local vehicle inspection company, e.g., "Combined together. The bus needs a scheduled inspection by PUSPAKOM. Then a valid bus permit and road tax. Don't forget insurance too" (Interviewee C). The need for all agency drivers to have a clean record and valid driving license poses the final indicator under 
transportation; e.g., "At least you must put that the bus driver must have a clean record. If he has a summon, he can't drive surely" (Interviewee A).

The fourth criteria for quality indicators for inbound tourism by travel agents are linked to the staff code of conduct with four sub-criteria agreed upon. The first sub-criteria relate to staff attitude. Indicators include politeness, courteousness, patience, friendliness, integrity, enthusiasm, proactiveness, and attentiveness. As mentioned by Interviewee C, "Honesty is very important for us." The second sub-criteria are self-appearance and self-presentation of the staff. Indicators agreed include being well-dressed, clean, and tidy as well as recognizable by others, e.g., "Polite, warm, enthusiastic, honest, passionate, attentive, provided with the Do's and Don'ts. Okay ... physical, dressed and clean. Neat and tidy. Easily recognized by clothing, nametags" (Interviewee B). The third important sub-criterion is communication skills with indicators such as being effective listeners and accurate in addressing customers' needs and requirements apart from fluency in English and other important foreign languages. Quality of employment is thus vital for the performance of travel agencies and adopted by Xin and Chan (2014). The importance of competent employees is also covered in the next criteria.

The final sub-criteria present the actual job of the tour guide and also the staff on duty. It is interesting to note that this is regarded as a sub-criterion on its own which shows how important this role is in the travel business as it is required by law; e.g., "It's a law, right? The tour guide is under the law" (Interviewee D). Indicators for the tour guide include legitimacy and certification of job appointment by the agency. For example, as mentioned by Interviewee B, "But, if I am an inbound tour operator, I am going to take a tour guide. That tour guide, we check if the tour operator is taking the right tour guide or not. As long as the tour guide has a license, that means passed already ... And as long as he got a license from MoTAC. Got a license, more than seven passengers, to me as a travel agent, that's sufficient." The tour guide should also assume an animated, lively, and friendly persona besides being clean and presentable. He also needs to be able to explain attractions properly. Another sub-criterion listed is the presence of the staff on duty. Indicators such as availability and attentiveness of the staff to tend to customers are deemed crucial. The staff should also be alert and obliging at all times, e.g., "Friendly surely. Alert and helpful. Because sometimes, like my office too. 5.30-6 o' clock they want to close already..." (Interviewee E).

The fifth criterion mentioned is the performance and management of inbound tours. Results revealed that there are 13 indicators developed altogether under these criteria. To start, all tour activities are bound by the regulations set by MoTAC. For example, as stated by Interviewee E, "The highest level is MoTAC. Any activities conducted by the state will have to report to MoTAC. I'm sure they have their own activities. So MoTAC allowed them to promote their state like that. So, in any case, MoTAC will refer to the state if any activity and what not This goes to mean that the ministry holds the highest say in terms of regulations for inbound tourism activities by local travel agencies." This was supported by Interviewee 2 who said that "If MoTAC doesn't control, then, everybody will do their own things. When they want to do activities, they must have the approval, or some form of green light is given. If 
not, the MoTAC has no control already." Other indicators include ensuring services or activities are detailed and clear in terms of itinerary, price, booking confirmation, records of time schedules, risks or hazards, and safety information and precautions. These are important as to ensure that the travel agency is in compliance with the standards given; e.g., "These are all important as a requirement too by MITA. So, we should emphasize this. Yes." (Interviewee D).

In terms of performance criteria of inbound tours, the interviewees agreed that tour guides should be trained and certified as part of continuous quality improvement of the tours. However as mentioned by Interviewee A, training should not be just for the tour guides but for all involved in the business; e.g., "But I think relevant training for the tour guide, staff and companies are very important. Besides training an individual in the companies, the companies itself must be trained like a rule of the engagement. Like, what the company does when they meet people. The company must have some standards, the criteria. The company itself. Not the individual, the company, the company." Since the focus group aims to come up with a certification program, in the end, the criteria set would be a standard for travel agents to know the rules of the game; e.g., "We will tell them the do's and the don'ts. We have to tell them what the certification is all about ensuring best practices and quality of services. We have to explain. Rather than you buy and take and then just you go. So, there must be quality in our services" (Interviewee E). This also relates to the quality of customer or visitor feedback process which is important for continuous improvement (Vázquez-Casielles et al. 2009).

Responsible tourism was also highlighted in terms of making sure that inbound tourism activities and tours uphold the preservation and conservation of local cultures and natural habitats. This is relevant to Tourism Productivity Nexus' aim stated by Interview A: "It is good that tours or activities ensure customers' satisfaction and needs, at all times, and also observe the approved guidelines for interacting with the culture, natural environment and people of the community." This finding supports the study by Xin and Chan (2014) on tour operators' agreement that responsible tourism must be in a position to safeguard the ecological, social, and cultural state of the destination. This is also foregrounded in next criteria, e.g., local guide quality and expertise. It pinpoints the substantial necessity for guides to be sensitized to the tour experience and ground operators with regard to the protection and management of the environment, local people, values, and cultural resources.

This sixth criterion is different from the mention on tour guide in the sense that the local guide is the expert local or native of the destination. As stated by Interviewee E, “There's a tour guide and there's a local guide. The local guide is the one on-site ... from the local community who knows the place at the back of his hand. So he should also be fit and licensed or certified." This was justified by Interviewee B who said that the local guide must also be trained and knowledgeable about "sustainable tourism" where "he must know the place very well, passionate in taking care of the place. His customer service and communication must be good ... on local traditions and environmental protection matters." This parallels Chan's (2010) description of sustainable tourism as "the preservation of the tourist destination and the capacity to satisfy tourists" (p. 30). 
The seventh criterion mentioned is on safety management at the travel agency. Two sub-criteria were listed, namely, equipment and general safety. Indicators posited under equipment involve providing adequate and practical safety equipment like fire extinguishers and first aid kits. Nonetheless, when it comes to safety, there is already a standard; as mentioned by Interviewee C, "This is standard. You follow. Safety cannot be compromised. You have to follow the standard procedures." Usage of the alarm system and CCTV is also important indicator under safety as well as prominent positioning of emergency exits or signs. Under general safety which is the second sub-criteria, the importance of training staff in first aid to handle emergency cases or crises and observe safety measures are laid down; e.g., "Staff needs to know how to handle emergencies ... to be trained in first aid" (Interviewee B). Safety measure compliance and preparedness comply with findings by Mat Som et al. (2015).

The final eighth criterion is related to sustainability practices of the travel operators. This links to the earlier-mentioned sustainable tourism in criteria six on local guides' role. The indicators are based on socioeconomic grounds like involving local communities in designing the itinerary of the tour, hiring them as local guides, hiring suppliers from the local community, and promoting locally made products and delicacies. This is supported by Interviewee B's statement: “Inbound travel agency describes the requirements for Tourism Productivity Nexus in the tourism industry to boost productivity through sharing and promoting of resources, enhancing quality customer services and ensuring customer's trust, ... all types of sustainability practices for the local destinations." This finding parallels Chan's (2010) argument on the need for more stakeholder input on how inbound tourism can benefit from sustainable tourism development.

As a whole, the results of the study revealed the interviewees' optimism toward developing standard indicators for better quality assurance certification for inbound tourism in general. As mentioned by Interviewee B, the development of the assessment for certification will benefit the inbound tourism business competency, e.g., "The idea of the assessment is not only to gauge the competency in their business. But, also to give the benefits to do the business. If they follow us [follow the certification], definitely they'll be successful." They also agreed on the fact that any kind of early certification should be led by the industry for the industry and on a voluntary basis. Hence, the certification must be affordable, easy to implement, and accepted by the small and medium industry players especially; e.g., "Okay any application fees should be at minimum cost. Application cost must be cheap" (Interviewee E). Findings also revealed the need for systematic monitoring of the inbound travel agency's certification plan that continually reflects the demands of the clientele and uplifts national productivity as outlined in the initiatives undertaken by the Tourism Productivity Nexus, under the Malaysia Productivity Blueprint 2016-2020. As said by one of the interviewees, "This action requires continuous monitoring for quality services First, the subject is monitoring quality service. That means the person whom we have already given the inbound travel agency." This supports the World Tourism Organization's (2004) stand on a monitoring system or 
Table 3 Total number of criteria, sub-criterion, and indicators

\begin{tabular}{l|l|c}
\hline No & Criteria (total number of sub-criteria and indicators) & Weightage (\%) \\
\hline 1. & First impression of the agency (5) & 5 \\
\hline 2. & Information (20) & 20 \\
\hline 3. & Facilities (6) & 6 \\
\hline 4. & Staff (20) & 20 \\
\hline 5. & Performance and management of inbound travel agency (12) & 24 \\
\hline 6. & Local guide quality and expertise (5) & 10 \\
\hline 7. & Safety and security (10) & 10 \\
\hline 8. & Sustainable practices (5) & 5 \\
\hline & Total (83 indicators) & 100 \\
\hline
\end{tabular}

certification that can be developed for continuous improvement based on the indicators.

In sum, the findings of this study showed eight main categories or criteria established. Within these criteria, sub-criteria were also mentioned as well as important indicators. Table 3 presents the eight criteria and 83 emergent sub-criteria and indicators.

\section{Conclusion and Recommendation}

This study discusses the possible quality indicators for Malaysian inbound travel agencies and how important they are for quality improvement in the service delivery standardization, from the perspective of Malaysian travel agency operators. The compliance with the minimum industry requirements and guidelines in the operation and management of the inbound travel agency is hoped to help improve the overall business process. These quality audit indicators for inbound travel agencies have been presented to members of Tourism Productivity Nexus and Malaysia Productivity Corporation for review. Tourism Productivity Nexus is the owner of the standards and the subsequent certification program. Tourism Productivity Nexus chartered the general principles for the standards: (1) target group: tourism small and medium companies and micro-players, (2) minimum requirements for indicators, (3) standards and certification programs to be developed are from and by the industry and for the industry. The standards to be developed should prepare the companies for higher-level standards, for instance, the national-level MyTQA, national-level standards, and international standards such as ISO.

Thus, it is expected that micro, small, and medium enterprises especially can implement the standards and subsequently get certified. Findings can be regarded as entrepreneurial strategies that will enhance productivity operations at the travel enterprise level. Global government officials can also adopt the findings in terms of their impact toward cultural, economic, ecological, and social outlooks. The 
recommendation from the key players is the establishment of an industry-level national certification awards to businesses and operators that hold high compliance level to the indicators set for certification. Inbound travel agencies must meet requirements with regard to suggested criteria of the quality audit by the industry experts as part of their positive contribution to the tourism business. As highlighted by the participants, the award will encourage the inbound travel agencies in the inbound business itself as it has been practiced by IATA for the outbound tour.

\section{References}

AlBattat, A. R., \& Mat Som, A. P. (2014). Emergency planning and disaster recovery in Malaysia hospitality industry. Procedia-Social and Behavioural Sciences, 144, 45-53.

Australian Tourism Industry Council. (2019). Star rating [online]. Retrieved April 26, 2020, from https://qualitytourismaustralia.com/.

Azahar, W. (2020). PM Najib launches Malaysia productivity blueprint to achieve 2020 vision [online]. Human Resources Online. Retrieved August 26, 2019, from https://www. humanresourcesonline.net/pm-najib-launches-malaysia-productivity-blueprint-to-achieve2020-vision/.

Budimir, V., Lutilsky, I. D., \& Idlbek, R. (2016). Performance indicators development in function of higher education quality monitoring. In M. Bilgin \& H. Danis (Eds.), Entrepreneurship, business and economics -Vol. 2. Eurasian studies in business and economics (Vol. 3/2). Cham: Springer.

Cater, C., \& Low, T. (2012). Focus groups. In L. Dwyer, A. Gill, \& N. Sitaram (Eds.), Handbook of research methods in tourism: Quantitative and qualitative approaches (pp. 352-364). Cheltenham: Edward Elgar.

Chan, J. K. L. (2010). Building sustainable tourism destination and developing responsible tourism: Conceptual framework, key issues and challenges. Tourism Development Journal-An International Research Journal, 8(1), 24-32.

Erlingsson, C., \& Brysiewicz, P. (2017). A hands-on guide to doing content analysis. African Journal of Emergency Medicine, 7, 93-99.

Font, X. (2005). Critical review of certification and accreditation in sustainable tourism governance [online]. Retrieved July 2, 2019, from http://www.crrconference.org/Previous_ conferences/downloads/font.pdf.

Hoffman, A. J., \& Henn, R. (2008). Overcoming the social and psychological barriers to green building. Organization and Environment, 21(4), 390-419.

Huang, S., \& Chen, G. (2016). Current state of tourism research in China. Tourism Management Perspectives, 20, 10-18.

Kalbaska, N., \& Cantoni, L. (2018). The use of eLearning strategies among travel agents in the United Kingdom, India and New Zealand. Journal of Teaching in Travel \& Tourism, 18(2), $138-158$.

King, L. M. (2019). Applying social practice theory to contemporary working practices in sustainable office buildings: Implications for the performance gap. $\mathrm{PhD}$. University of the West of England.

Mak, L. M. (2015). Travel agencies' perception of ISO 9001 certification. The TQM Journal, 27(6), 741-751.

Malaysia Tourism Quality Assurance (MyTQA). (2020). Malaysia tourism quality assurance [online]. Retrieved April 27, 2020, from http://www.motac.gov.my/en/services/registration/ mytqa. 
Mat Som, A. P., Aun, O. C., \& AlBattat, A. R. (2015). Tourists' perception on crisis and the impact of instability on destination safety in Sabah, Malaysia. American-Eurasian Journal of Sustainable Agriculture, 15(96), 96-103.

Medina, L. K. (2005). Ecotourism and certification: Confronting the principles and pragmatics of socially responsible tourism. Journal of Sustainable Tourism, 13(3), 281-295.

Mellina, J. P., \& Reino, S. (2019). Average scores integration in official star rating scheme. Journal of Hospitality and Tourism Technology, 10(3). https://doi.org/10.1108/JHTT-07-2017-0050.

Ministry of Tourism, Arts and Culture Malaysia. (2020). Travel agency [online]. Retrieved April 27, 2020, from http://www.motac.gov.my/en/services/license-application/travel-agency/cate gory/35-versi-bahasa-inggeris.

Norway. (2020). Sustainability [online]. Retrieved June 16, 2019, from https://www.visitnorway. com/travel-trade/sustainability/.

Perramon, J., Llorenç, B.-F. L., \& Amat, O. (2015). Quality practices in travel agencies A mediating factor in non-financial indicators of advanced information systems. Industrial Management \& Data Systems, 115(7), 1325-1340.

Picken, F. (2017). Qualitative tourism methods. Clavendon Hall: Channelview Publications.

Set, K. (2013). Tourism Small and Medium Enterprises (TSMEs) in Malaysia. International Journal of Business and Social Science, 4(16), 58-66.

Singh, S., Dash, T. R., \& Vashko, I. (2016). Tourism, ecotourism and sport tourism: The framework for certification. Marketing Intelligence \& Planning, 34(2), 236-255.

Tarantino, E., De Falco, I., \& Scafuri, U. (2019). A mobile personalized tourist guide and its user evaluation. Information Technology \& Tourism, 21, 413-455.

Teng, C.-C., Horng, J.-S., Hu, M.-L. M., Chien, L.-H., \& Shen, Y.-C. (2012). Developing energy conservation and carbon reduction indicators for the hotel industry in Taiwan. International Journal of Hospitality Management, 31, 199-208.

Tourism Malaysia. (2019). Malaysia tourism statistics in brief [online]. Retrieved April 26, 2020, from https://www.tourism.gov.my/statistics.

Tourism Productivity Nexus. (2019). Malaysia productivity blueprint: Driving productivity of the nation [online]. Retrieved April 2020 26, from http://www.wayup.my.

Vázquez-Casielles, R., Suárez-Álvarez, L., \& Del Río-Lanza, A. B. (2009). Customer satisfaction and switching barriers: Effects on repurchase intentions, positive recommendations, and Price tolerance. The Journal of Applied Psychology, 39(10), 2275-2302. https://doi.org/10.1111/ j.1559-1816.2009.00526.x.

World Tourism Organization. (2004). Indicators of sustainable development for tourism destinations: A guidebook. Madrid, Spain: World Tourism Organization.

Xin, T. K., \& Chan, J. K. L. (2014). Tour operator perspectives on responsible tourism indicators of Kinabalu National Park. Procedia - Social and Behavioral Sciences, 144, 25-34. 